\title{
A randomised controlled trial of short term growth and collagen turnover in asthmatics treated with inhaled formoterol and budesonide
}

\author{
Carsten Heuck, Lene Heickendorff, Ole D Wolthers
}

\begin{abstract}
Aims-To determine effects on short term growth and collagen turnover of adding formoterol (Eformoterol) to half the glucocorticoid dose in children with asthma, treated with inhaled budesonide (Pulmicort Turbuhaler).

Design-A randomised double blind, placebo controlled crossover study with two six-week periods.

Setting-Outpatient clinic in secondary referral centre.

Subjects-A total of 27 prepubertal children aged $6-13$ years.

Interventions-Formoterol $12 \mu \mathrm{g}$ and dry powder budesonide $100 \mu \mathrm{g}$ twice daily in one period; placebo and dry powder budesonide $200 \mu \mathrm{g}$ twice daily in the other. Outcome measures-Primary outcome measures were lower leg growth rate, and serum and urine markers of type $I$ and type III collagen turnover. Secondary outcome measures were inflammation markers in serum, and parameters of asthma control.

Results-During budesonide $200 \mu \mathrm{g}$ twice daily treatment, mean lower leg growth rate was $0.14 \mathrm{~mm} /$ week $(p=0.02)$ lower than during the formoterol and budesonide period. Similar statistically significant effects on markers of collagen turnover were found, whereas inflammation markers and asthma control did not vary statistically significantly between the two periods.

Conclusions-In children treated with inhaled glucocorticoids, halving the dose and adding formoterol is associated with faster short term growth and an increase in markers of collagen turnover, with no loss of asthma control. (Arch Dis Child 2000;83:334-339)
\end{abstract}

Keywords: asthma; growth; inhaled glucocorticoids; formoterol; collagen turnover; bronchial inflammation

Prophylactic anti-inflammatory treatment with glucocorticoids in asthmatic children should aim at optimal disease control and make normal development and growth possible. ${ }^{1}$ In most schoolchildren this can be achieved with recommended daily doses of 200-400 $\mu \mathrm{g}$ of an inhaled glucocorticoid administered from a metered dose inhaler with a spacer, or with 100-200 $\mu \mathrm{g}$ from a dry powder inhalation device. $^{23}$ Children with severe asthma, however, may require higher doses. As the risk of systemic effects of exogenous glucocorticoids depends on dose, systemic adverse effects may be seen in these children. ${ }^{4}$ Daily doses of budesonide $800 \mu \mathrm{g}$ from a metered dose inhaler with a spacer, and dry powder budesonide and beclomethasone dipropionate $400 \mu \mathrm{g}$ have been found to suppress growth rate and collagen turnover. ${ }^{4-7}$ Although it remains to be properly assessed whether final height may be attained in children during continuous, long term treatment with inhaled glucocorticoids, the need for developing administration regimens which at the same time make disease control possible and alleviate the risk of adverse effects on growth and collagen turnover has been emphasised. ${ }^{89}$ Recently, it was reported that combining long acting, inhaled $\beta_{2}$ agonists, salmeterol xinoate or formoterol fumarate, with an inhaled glucocorticoid, may lead to a greater improvement in control of asthma than treatment with the inhaled glucocorticoid alone. ${ }^{10-13}$ The aim of the present study was to see whether addition of inhaled formoterol to half the glucocorticoid dose in children with asthma requiring high doses of inhaled glucocorticoids, affects growth and collagen turnover.

\section{Patients and methods}

PATIENTS

Calculation of sample size was based on assessment of the standard deviation of mean knemometric growth rates in our previous studies. ${ }^{14}$ As we wanted to allow for assessment of adverse effects associated to sex, the number of patients was doubled. Fourteen boys and 13 girls aged 6.1-13.5 (mean 9.5) years from an outpatient secondary referral centre participated in the study. Duration of asthma was 1.4-9.5 (mean 4.5) years. During that period the children had been treated with inhaled dry powder budesonide $200 \mu \mathrm{g}$ twice daily or equipotent doses of other inhaled glucocorticoids and administration devices. During the month before study entry, disease activity was controlled with inhaled dry powder budesonide $200 \mu \mathrm{g}$ twice daily. Height at study entry varied from 113.6 to $161.8 \mathrm{~cm}$ (mean $134.4 \mathrm{~cm}$ ), height standard deviation score from -2.3 to 2.1 (mean -0.3), and weight from 19.4 to $50.8 \mathrm{~kg}$ (mean $32.8 \mathrm{~kg}$ ). All children were prepubertal, according to the Tanner rating of puberty. The period of study was January to May, and all children were included over one week.

The study was conducted in accordance with good clinical practise guidelines issued by the European Commission in 1990 and the Decla- 
ration of Helsinki. Approval by the local ethics committee and informed consent were obtained from all children and their families.

\section{STUDY DESIGN}

The design was a randomised double blind, placebo controlled two period crossover trial with treatment periods of six weeks duration. The children were allocated to twice daily treatment with dry powder budesonide $100 \mu \mathrm{g}$ and dry powder formoterol fumarate $12 \mu \mathrm{g}$, or twice daily inhaled dry powder budesonide 200 $\mu \mathrm{g}$ and placebo. Treatment order was allocated by a computerised randomisation scheme prepared in balanced blocks. Conventional dry powder placebo and budesonide (Pulmicort Turbuhaler), placebo and formoterol Aerolizer (Eformoterol) devices were used. In the budesonide-formoterol period the Turbuhaler delivered $100 \mu \mathrm{g}$ budesonide, and the Aerolizer capsule $12 \mu \mathrm{g}$ formoterol per activated dose. In the budesonide-placebo period the Turbuhaler delivered $200 \mu \mathrm{g}$ budesonide per activation and the capsules in the Aerolizer contained placebo. During both periods one activated dose from the Turbuhaler and one capsule from the Aerolizer were inhaled at 0730 and 1900. The inhalation devices were delivered in identical boxes labelled with patient and period numbers and prescription. The children were instructed to brush their teeth after the inhalations and to spit out the rinsing water. To assess compliance the Turbuhalers were weighed before and after each period, and the number of formoterol capsules was counted. If less than $80 \%$ of the prescribed dose was taken the patient would be excluded from analysis. No other drugs apart from the study medication and rescue inhaled terbutaline (Bricanyl Turbuhaler, $0.5 \mathrm{mg}$ per inhalation) were allowed during the study period. Exacerbations in asthma requiring intensified treatment with glucocorticoids would lead to withdrawal from the study.

\section{ASSESSMENT OF GROWTH}

Lower leg length measurements were performed with the knemometer on the first day of week 1 , and on the last day of weeks 2 and 6 in each period. ${ }^{15}$ All measurements were performed by the same trained observer. The children attended the clinic in the afternoon (between 1300 and 1800) and were measured at the same time at every visit (within an hour). At each visit four estimations of lower leg length were made, the mean of the last three being used for analysis.

SERUM AND URINE ANALYSES

On the last day of the two treatment periods, urine was collected at 0700 after an overnight fast and stored at $<5^{\circ} \mathrm{C}$ until the children attended the clinic later that day. Blood samples were taken at the same time (that is, within one hour) between 1300 and 1800 . The samples were centrifuged at $4000 \mathrm{rpm}$ for 10 minutes within one hour, after which they and the urine samples were stored at $-80^{\circ} \mathrm{C}$ and batch assayed at completion of the study.
Markers of type I and III collagen turnover Serum concentrations of the carboxy terminal propeptide of type I procollagen (PICP), ${ }^{16}$ the amino terminal propeptide of type I procollagen (PINP), ${ }^{17}$ the carboxy terminal pyridinoline cross linked telopeptide of type I collagen (ICTP),${ }^{18}$ and the amino terminal propeptide of type III procollagen (PIIINP) ${ }^{19}$ were determined by radioimmunoassays based on human antigen (Orion Diagnostica, Oulunsalo, Finland) Intra- and interassay variations were $<5 \%$ and $<7 \%$ for all assays. Normal serum ranges have been published previously. ${ }^{17} 2021$ Urinary deoxypyridinoline (DPD) was measured by a solid phase chemiluminescent enzyme immunoassay on an automated instrument (Immulite Pyrilinks-D, Diagnostica Products Corporation, Los Angeles, California). The assay specifically detects non-peptide bound DPD. ${ }^{22}$ Urinary cross linked $\mathrm{N}$-telopeptides of type I collagen (NTx) were measured by the Osteomark radioimmunoassay (Ostex, Seattle, Washington). ${ }^{23}$ Sample dilutions were made with urine containing low concentrations of NTx as recommended by the manufacturer. Intra- and interassay variations were $8 \%$ and $9 \%$, and $8 \%$ and $12 \%$, respectively, for the DPD and NTx assays. Normal ranges of the DPD assay in children are not available, whereas preliminary NTx data standardised for creatinine excretion have been published. $^{24}$

\section{Markers of airway inflammation}

The serum concentration of eosinophil cationic protein (ECP) and eosinophil protein $\mathrm{X}$ (EPX) in urine were determined using specific radioimmunoassays (Pharmacia \& Upjohn, Sweden). ${ }^{25}{ }^{26}$ Intra- and interassay variations were $6 \%$ and $7 \%$, and $5 \%$ and $9 \%$, respectively. Normal reference values for serum ECP and urine EPX standardised for creatinine are available..$^{25-27}$

Creatinine in urine was determined by standard laboratory methods.

PULMONARY FUNCTION AND SYMPTOMS

Using a dry bellows spirometer (Vitalograph), pulmonary function was assessed by measuring forced expiratory volume in one second $\left(\mathrm{FEV}_{1}\right)$ and forced vital capacity (FVC) on the last day of weeks 2 and 6 in the treatment periods. The best of three measurements was recorded. Peak expiratory flow rates, the best of three measurements, were recorded with the Mini-Wright peak flow meter at home, in the morning and in the evening before medication. Day and night asthma symptoms were recorded in diaries according to a four point scale ( 0 indicating no symptoms; 3 indicating severe symptoms), and the use of rescue terbutaline was recorded.

\section{STATISTICS}

Growth rate was calculated as the difference in lower leg length determined at the end of weeks 6 and 2, divided by the time interval between the measurements. ${ }^{15}$ Data were tested for and found to fulfil conditions for normal distribution. Statistical analysis was performed by Student's paired $t$ test. For assessment of lung 

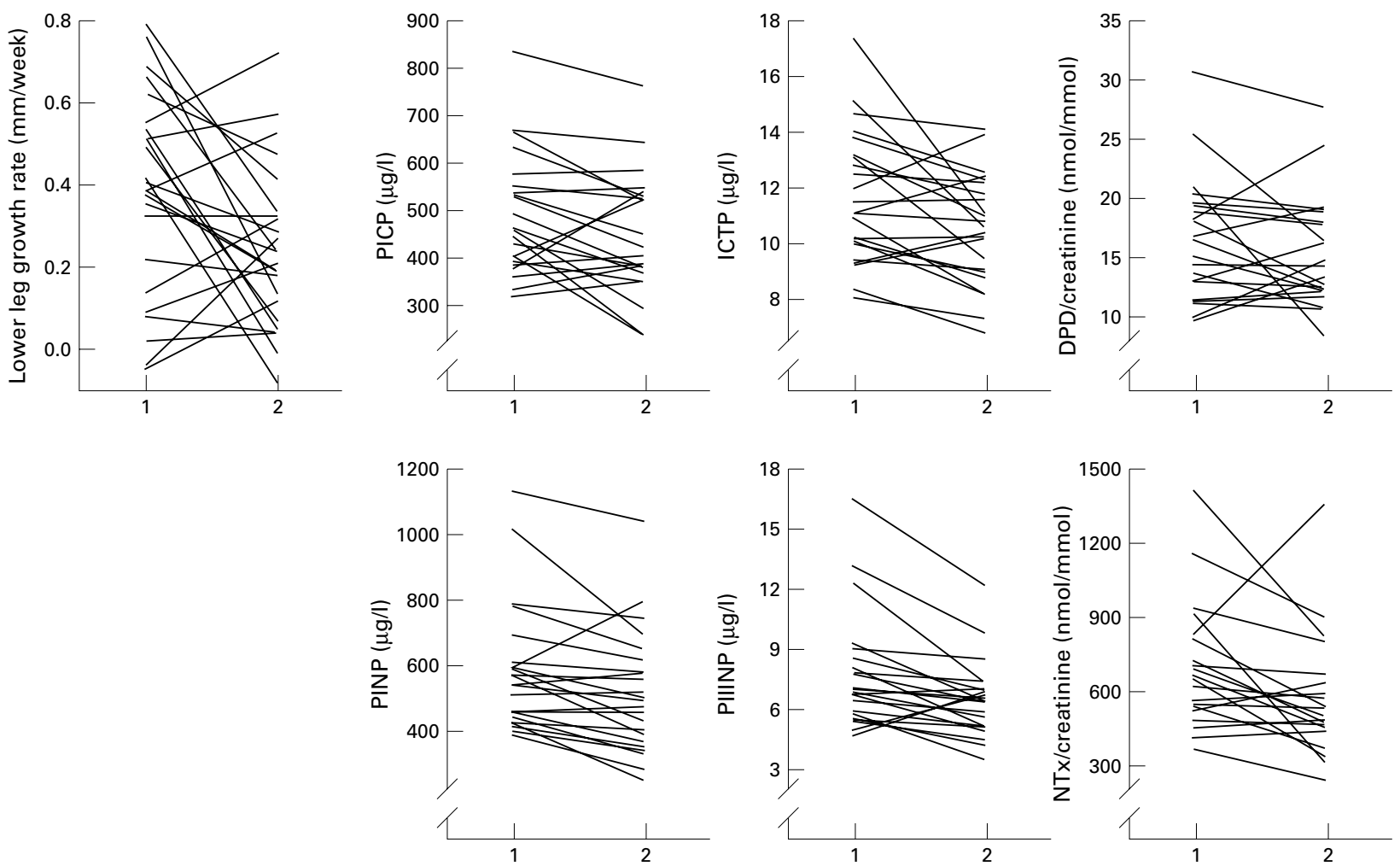

Figure 1 Individual lower leg growth rates in 24, serum PICP, PINP, ICTP, and PIIINP in 23, and urine NTx and DPD in 21 children with asthma during twice daily treatment with formoterol $12 \mu \mathrm{g}$ and budesonide $100 \mu \mathrm{g}$ (1) and twice daily treatment with placebo and budesonide 200 $\mu \mathrm{g}$ (2).

function data, $\mathrm{FEV}_{1} / \mathrm{FVC}$ ratios were used. ${ }^{28}$ The ratios were tested by one way analysis of variance for repeated measurements. All data were tested for period and carry over effects. The $5 \%$ level of significance was used.

\section{Results}

Twenty four children completed the study according to the protocol. During budesonideplacebo treatment a girl and a boy were withdrawn from the study because of acute exacerbations requiring treatment with systemic glucocorticoids. A boy failed to complete the study because his family moved away. During the first period a girl decided not to have blood samples taken, and three girls failed to collect urine during both periods. Fourteen children were randomised to receive budesonide and formoterol treatment in the first period, 10 children to receive budesonide and placebo first. No period or carry over effects on any of the measured parameters were found. Compliance with dosage regimen varied from
$88 \%$ to $100 \%$ (mean $97 \%$ ) and from $90 \%$ to $100 \%$ (mean $98 \%$ ) for formoterol and budesonide, respectively. No variations in compliance between the two treatment periods were detected (formoterol: $\mathrm{p}=0.48, t=-0.7,95 \%$ confidence interval (CI) $-2.8 \%$ to $1.4 \%$; budesonide: $\mathrm{p}=0.51, t=-0.7,95 \% \quad \mathrm{CI}$ $-2.4 \%$ to $1.3 \%$ ).

Figure 1 and table 1 show individual and group mean lower leg growth rates, serum and urine concentrations of collagen markers, and the results of the statistical comparisons. During budesonide $200 \mu \mathrm{g}$ twice daily treatment, mean lower leg growth rate was 0.14 $\mathrm{mm} /$ week $(\mathrm{p}=0.02)$ lower than during the formoterol and budesonide period. Serum PICP, PINP, ICTP, and PIIINP, and urine NTx concentrations were reduced by $44 \mu \mathrm{g} / 1$ $(\mathrm{p}=0.04), \quad 64 \quad \mu \mathrm{g} / \mathrm{l} \quad(\mathrm{p}=0.004), \quad 1.1 \quad \mu \mathrm{g} / 1$ $(\mathrm{p}=0.009), 1.2 \mu \mathrm{g} / \mathrm{l}(\mathrm{p}=0.002)$, and 126 $\mathrm{nmol} / \mathrm{mmol}$ creatinine $(\mathrm{p}=0.02)$, respectively, during the budesonide $200 \mu \mathrm{g}$ twice daily period.

Table 1 Group means of lower leg growth rates, serum PICP, PINP, ICTP, and PIIINP, and urine NTx and DPD

\begin{tabular}{|c|c|c|c|}
\hline & $\begin{array}{l}\text { Formoterol and } \\
\text { budesonide }\end{array}$ & $\begin{array}{l}\text { Placebo and } \\
\text { budesonide }\end{array}$ & $\begin{array}{l}p \text { and } t \text { values; } 95 \% \text { confidence interval for the } \\
\text { difference }\end{array}$ \\
\hline Lower leg growth rate (mm/week) & $0.39(0.05)$ & $0.25(0.04)$ & $\mathrm{p}=0.02, t=2.6 ; 0.03$ to $0.26 \mathrm{~mm} /$ week \\
\hline $\operatorname{PICP}(\mu \mathrm{g} / \mathrm{l})$ & $490 \quad(27)$ & $447 \quad(28)$ & $\mathrm{p}=0.04, t=2.2 ; 2$ to $85 \mu \mathrm{g} / 1$ \\
\hline PINP $(\mu \mathrm{g} / \mathrm{l})$ & 582 & 517 & $\mathrm{p}=0.004, t=3.2 ; 22$ to $107 \mu \mathrm{g} / \mathrm{l}$ \\
\hline $\operatorname{ICTP}(\mu \mathrm{g} / \mathrm{l})$ & $11.7 \quad(0.5)$ & $10.5(0.4)$ & $\mathrm{p}=0.009, t=2.9 ; 0.3$ to $1.9 \mu \mathrm{g} / \mathrm{l}$ \\
\hline PIIINP $(\mu \mathrm{g} / \mathrm{l})$ & $7.7(0.6)$ & $6.4(0.4)$ & $\mathrm{p}=0.002, t=3.6 ; 0.5$ to $2.0 \mu \mathrm{g} / 1$ \\
\hline $\mathrm{NTx} /$ creatinine $(\mathrm{nmol} / \mathrm{mmol})$ & 693 & $566 \quad(54)$ & $\mathrm{p}=0.02, t=2.4 ; 18$ to $234 \mathrm{nmol} / \mathrm{mmol}$ creatinine \\
\hline $\mathrm{DPD} /$ creatinine $(\mathrm{nmol} / \mathrm{mmol})$ & $16.6(1.2)$ & $15.5(1.0)$ & $\mathrm{p}=0.25, t=1.2 ;-0.9$ to $3.1 \mathrm{nmol} / \mathrm{mmol}$ creatinine \\
\hline
\end{tabular}

Serum parameters were measured in 23 asthmatic children (12 boys and 11 girls), and urine parameters in 12 boys and 9 girls during treatment with inhaled formoterol $12 \mu \mathrm{g}$ and budesonide $100 \mu \mathrm{g}$ twice daily, and placebo and budesonide $200 \mu \mathrm{g}$ twice daily. Results expressed as mean (SEM).

${ }^{\star}$ Formoterol and budesonide versus placebo and budesonide. 

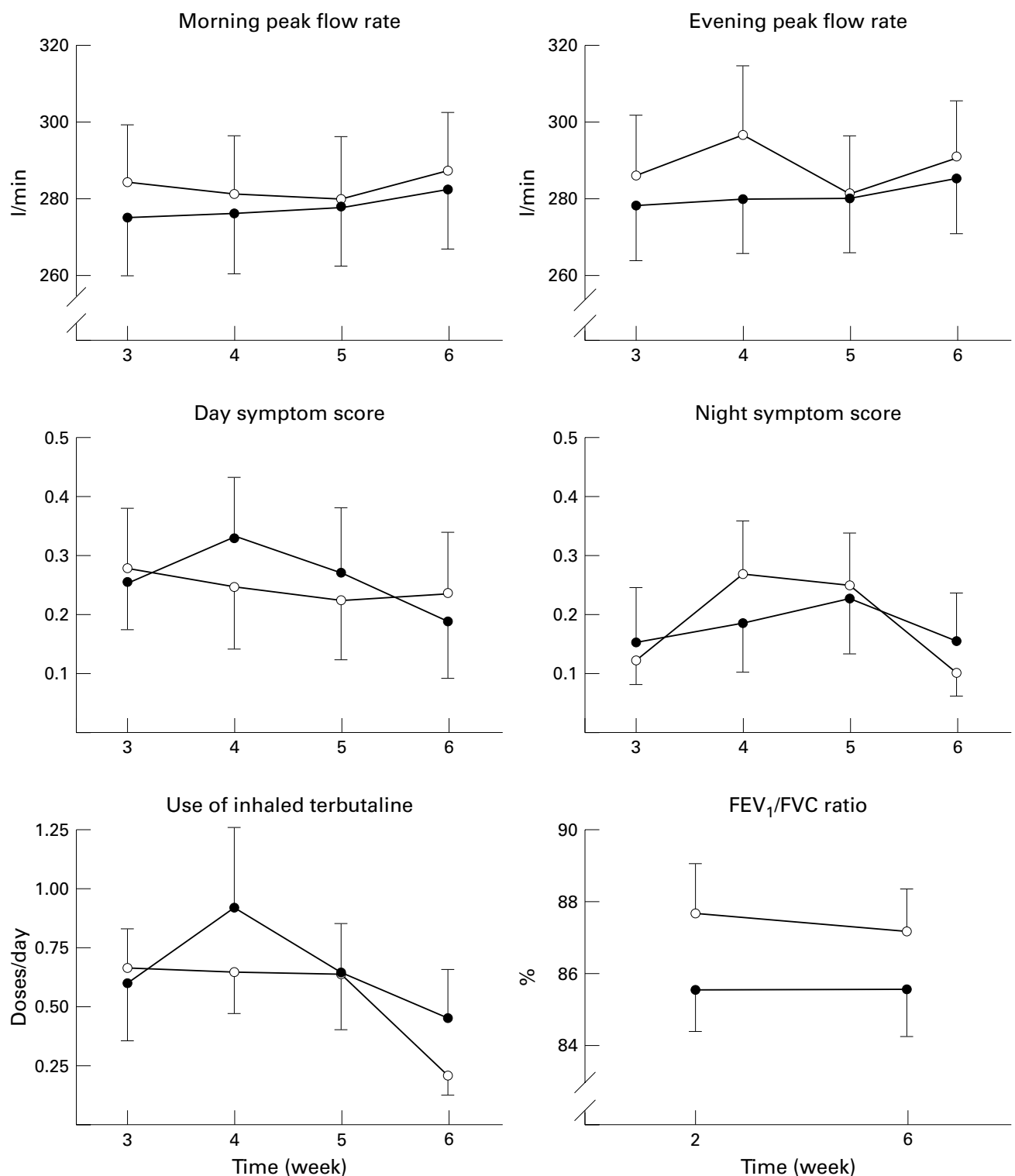

Figure 2 Group means of peak expiratory flow rates, symptom scores, use of rescue inhaled terbutaline, and FEV in 24 children with asthma during twice daily treatment with formoterol $12 \mu \mathrm{g}$ and budesonide $100 \mu \mathrm{g}$ (open circles) and twice daily treatment with placebo and budesonide $200 \mu \mathrm{g}$ (closed circles).

Serum ECP and urine EPX showed no significant variations: during treatment with budesonide $200 \mu \mathrm{g}$ twice daily, serum ECP and urine $\mathrm{EPX} /$ creatinine concentrations were 9.7 (SEM 1.6) $\mu \mathrm{g} / \mathrm{l}$ and 139 (21) $\mu \mathrm{g} / \mathrm{mmol}$; during formoterol and budesonide treatment concentrations were $9.0(1.1) \mu \mathrm{g} / \mathrm{l}$ and 142 (18) $\mu \mathrm{g} / \mathrm{mmol}$, respectively $(\mathrm{ECP}: \mathrm{p}=0.70$, $t=-0.4,95 \%$ CI -4.2 to $2.9 \mu \mathrm{g} / 1 ; \mathrm{EPX} /$ creatinine: $\mathrm{p}=0.87, t=0.2,95 \% \mathrm{CI}-30$ to 36 $\mu \mathrm{g} / \mathrm{mmol}$ ).

Figure 2 shows group means of peak expiratory flow rates, symptom scores, consumption of short acting $\beta_{2}$ agonists, and $\mathrm{FEV}_{1} / \mathrm{FVC}$ ratio. Mean peak expiratory flow rates (morning: $\mathrm{p}=0.33, t=0.99,95 \% \mathrm{CI}-6$ to $161 / \mathrm{min}$; evening: $\mathrm{p}=0.29, t=1.1,95 \% \mathrm{CI}-7$ to 29 $1 / \mathrm{min}$ ), symptom scores (day: $\mathrm{p}=0.55$, $t=0.60,95 \%$ CI -0.11 to 0.20 ; night: $\mathrm{p}=0.64, t=0.47,95 \% \mathrm{CI}-0.10$ to 0.15$)$, and consumption of $\beta_{2}$ agonists $(\mathrm{p}=0.56$, $t=-0.6,95 \%$ CI -0.48 to $0.27 \mathrm{puffs} /$ day) showed no statistically significant variations. Compared to the budesonide $200 \mu \mathrm{g}$ twice daily period, mean $\mathrm{FEV}_{1}$ in week 2 was significantly higher $(\mathrm{p}=0.04, t=2.2,95 \% \mathrm{CI}-0.01$ to 0.17 ) during the formoterol and budesonide period, whereas no significant difference ( $\mathrm{p}=0.32, t=1.0,95 \% \mathrm{CI}-0.02$ to 0.06 ) was found in week 6 .

Separate analyses of boys and girls revealed no sex differences in any of the outcome measures.

\section{Discussion}

The principal aim of the present study was to assess whether short term treatment with twice daily inhaled formoterol $12 \mu \mathrm{g}$ and dry powder budesonide $100 \mu \mathrm{g}$ reduces the risk of systemic effects on growth and collagen turnover, compared to a double dose of budesonide in children requiring long term treatment with high doses of inhaled glucocorticoid. Primary outcome measures were lower leg growth rates and markers of type I and III collagen turnover. 
The sensitivity of knemometry in the assessment of growth suppressive effects of exogenous glucocorticoids depends on a crossover design. ${ }^{14}$ The participating children should be enrolled in the study almost simultaneously, and the total study period should be restricted to less than three or four months. Considering both these conditions and the disease severity of the study population, for methodological and ethical reasons run in or wash out periods without any anti-inflammatory treatment could not be included in the present trial. Changes in lower leg growth rates and markers of collagen turnover in response to variations in dose of exogenous glucocorticoid, however, seem to occur well within two weeks. ${ }^{29-31}$ Therefore, to avoid carry over effects, the first two weeks of each period were excluded from analysis. The results of the statistical analyses proved that this was achieved, confirming the sensitivity of the study design.

The observed mean growth rate during formoterol $12 \mu \mathrm{g}$ and dry powder budesonide $100 \mu \mathrm{g}$ twice daily treatment is in line with growth rates previously observed in children with mild asthma during dry powder budesonide $100 \mu \mathrm{g}$ twice daily and placebo treatments, and with growth rates in normal children measured during the same time of the year. ${ }^{32-34}$ Though no firm conclusions can be drawn as the present trial did not include a placebo period, the finding of a higher growth rate during treatment with formoterol $12 \mu \mathrm{g}$ and dry powder budesonide $100 \mu \mathrm{g}$ twice daily compared to budesonide $200 \mu \mathrm{g}$ twice daily suggests that in children requiring regular inhaled glucocorticoids growth may not be affected when combined treatment is given. The slower growth observed during the twice daily dry powder budesonide $200 \mu \mathrm{g}$ period is comparable to the results from a crossover knemometry study which applied two week treatment periods. ${ }^{32}$

Serum concentrations of PICP and PINP reflect synthesis, and ICTP, urine NTx, and DPD represent degradation of type I collagen, primarily in bone. ${ }^{17} 22233536$ Serum concentrations of PIIINP correlate with synthesis of type III collagen which is present in connective tissue throughout the body. ${ }^{21}$ The findings of suppressed concentrations of PICP, PINP, ICTP, and PIIINP during the twice daily budesonide $200 \mu \mathrm{g}$ period are consistent with observations in previous studies of equipotent administration of budesonide and beclomethasone dipropionate, indicating suppressive effects on type I (bone) and type III collagen turnover. ${ }^{467}$ Studies of the effect of inhaled glucocorticoids on urine DPD have been more conflicting. Some have found suppression, but others have not, in children treated with twice daily $400 \mu \mathrm{g}$ budesonide from a metered dose inhaler with a spacer. ${ }^{637}$ In one study, twice daily dry powder budesonide $400 \mu \mathrm{g}$ was associated with suppressed DPD concentrations. ${ }^{31}$ To some extent the discrepancies may be a result of biological variations in urine DPD. ${ }^{29}{ }^{38}$ However, recent reports suggest that the sensitivity of urine crosslinks assays for assessment of bone resorption activity may depend on whether total or peptide bound concentrations are measured. Discrepancies in decreases between free, total, and peptide bound crosslinks have been found in several studies of biphosphonates and after vitamin $\mathrm{D}$ and calcium supplementation. ${ }^{39-42}$ These observations indicate that changes in bone resorption are reflected with a greater sensitivity with assays that determine peptide bound crosslinks than with free crosslinks, and it has been suggested that the excretion of the markers may be differently influenced. ${ }^{43}$ We therefore wanted to include a new marker of type I collagen degradation, NTx, which has been proven sensitive in various conditions of bone resorption. ${ }^{23}{ }^{38}$ The NTx assay measures only the peptide bound fraction of urine crosslinks. The finding of suppressed urine NTx during the twice daily budesonide $200 \mu \mathrm{g}$ period which was paralleled by suppressed serum ICTP concentrations suggests that NTx may be more sensitive than DPD for detection of glucocorticoid induced effects on growth in children treated with inhaled glucocorticoids.

Eosinophilic inflammation of the airways is related to disease activity. Activated eosinophils release the cytotoxic granula ECP and EPX which may be detected in serum and urine, respectively, being sensitive markers of eosinophil activation and airway inflammation. ${ }^{25} 2644$ Corresponding with an improvement in symptom control, raised concentrations of serum ECP and urine EPX in children with poorly controlled asthma were normalised during treatment with inhaled glucocorticoids. ${ }^{25}{ }^{26}{ }^{44} \mathrm{In}$ the present study serum ECP and urine EPX concentrations were almost identical during the formoterol $12 \mu \mathrm{g}$ and dry powder budesonide $100 \mu \mathrm{g}$ twice daily, and budesonide $200 \mu \mathrm{g}$ twice daily periods. This was paralleled by the observation of no statistically significant variations in peak expiratory flow rates, in symptom scores or in the use of rescue terbutaline, indicating a similar control of bronchial inflammation. It may be suggested that these findings could have been caused by overtreatment during treatment with the higher dose of budesonide. However, the observed $\mathrm{FEV}_{1}$ data do not support that. Furthermore, the results are in accord with reports of unaffected bronchial hyperreactivity as measured by provocation tests and improvements in lung function and symptom control when long acting $\beta_{2}$ agonists were added to inhaled glucocorticoids in symptomatic patients..$^{10} 13$ Addition of salmeterol to inhaled beclomethasone dipropionate $500 \mu \mathrm{g}$ provided better symptom control than did doubling the dose of the glucocorticoid. ${ }^{13}$ Finally, though formoterol induced effects on acute inflammatory changes cannot be ruled out, regular treatment with long acting $\beta_{2}$ agonists do not seem to modify chronic airway inflammation. ${ }^{10}$ Therefore, although the present study was not designed or powered to test control of lung function during the two treatment regimens, when the inflammation markers are taken together with the measures of symptoms and lung function, the results indicate that disease activity was well controlled during combination therapy with formoterol and budesonide. 
Short term knemometry and serum and urine markers of type I and III collagen turnover may be the most sensitive markers of systemic activity of inhaled glucocorticoids available in children. ${ }^{26737}$ To what extent glucocorticoid induced suppression of the measures may correlate with an increased risk of final height suppression or osteoporosis during long term treatment still remains to be clarified. On the other hand, if an inhaled glucocorticoid is not associated with suppressive effects on growth rates or markers of collagen turnover in short term assessments, deleterious long term effects are most unlikely. Considering that long term combination therapy with formoterol and budesonide effectively controls asthma symptoms,${ }^{10}$ we believe that the present study has provided important new information for the clinical management of children requiring inhaled glucocorticoids. Formoterol $12 \mu \mathrm{g}$ twice daily can be added to half the dose of the inhaled glucocorticoid; this reduces the risk of suppressive effects on growth and collagen turnover.

Inflammation marker assessments were performed at Research and Development Laboratories, Pharmacia \& Upjohn, Diagnosics AB, Uppsala, Sweden, supervised by senior scientist Christer Peterson. Mini Wright peak flow meters were supplied by Simonsen and Weel A/S, Copenhagen, Denmark.

1 Shaw NJ, Framer NC, Welles RR. Asthma treatment and growth. Arch Dis Child 1998;77:284-6.

2 Wolthers OD. Long, intermediate and short term growth studies in asthmatic children treated with inhaled glucocorticosteroids. Eur Respir f 1996;9:821-9.

3 Pedersen S, O'Byrne P. A comparison of the efficacy and safety of inhaled corticosteroids in asthma. Allergy 1997;52 $1-34$.

4 Wolthers OD, Juul A, Hansen M, Müller J, Pedersen S. The insulin-like growth factor axis and collagen turnover in asthmatic children treated with inhaled budesonide. Acta Paediatr Scand 1995;84:393-7.

5 Doull IJ, Freezer NJ, Holgate ST. Growth of prepubertal children with mild asthma treated with inhaled beclomethasone dipropionate. Am $\mathcal{f}$ Respir Crit Care Med 1995;151:1715-19.

6 Heuck C, Wolthers OD, Hansen M, Kollerup G. Short-term growth and collagen turnover in asthmatic adolescents treated with the inhaled glucocorticoid budesonide. Steroids 1997;62:659-64.

7 Wolthers OD, Hansen M, Juul A, Nielsen HK, Pedersen S. Urine cortisol excretion, knemometry and measures of the insulin-like growth factor axis and collagen turnover in the assessment of systemic activity of inhaled glucocorticosteroids in children. Pediatr Res 1997;41:44-50

8 Global Initiative for Asthma. Global strategy for asthma management and prevention. Publication no. 95-3659. Washington, DC: Heart, Lung and Blood Institute, 1995.

9 Ayres JG, Barnes PJ, Bellamy D, et al. The British guidelines on asthma management-1995 review and position statement. Thorax 1997;52(suppl 1).

10 Pauwels RA, Lofdahl CG, Postma DS, et al. Effect of inhaled formoterol and budesonide on exacerbations of asthma. Formoterol and Corticosteroids Establishing Therapy (FACET) International Study Group. $N$ Engl $尹$ Med 1997;337:1405-11.

11 Russell G, Williams DA, Weller P, Price JF. Salmeterol xinafoate in children on high dose inhaled steroids. Ann Allergy Asthma Immunol 1995;75:423-8.

12 Wilding P, Clark M, Coon JT, et al. Effect of long-term treatment with salmeterol on asthma control: a double blind, randomised crossover study. BMF 1997;314:1441-6.

13 Woolcock A, Lundback B, Ringdal N, Jacques LA Comparison of addition of salmeterol to inhaled steroids with doubling of the dose of inhaled steroids. Am $\mathcal{F}$ Respir Crit Care Med 1996;153:1481-8.

14 Wolthers OD. Methodological aspects of short-term knemometry in the assessment of exogenous glucocorticoidinduced growth suppression in children. Ann Hum Biol 1997;24:539-46.

15 Heuck C, Wolthers OD. Calculation of knemometric growth rates in group studies of children treated with exogenous glucocorticoids. Ann Hum Biol 1997;24:411-18.

16 Melkko J, Niemi S, Risteli L, Risteli J. Radioimmunoassay of the carboxyterminal propeptide of human type I procollagen. Clin Chem 1990;36:1328-32.

17 Melkko J, Kauppila S, Niemi S, et al. Immunoassay for intact amino-terminal propeptide of human type I procollagen. Clin Chem 1996;42:947-54

18 Risteli J, Elomaa I, Niemi S, Novamo A, Risteli L. Radioimmunoassay for the pyridinoline cross-linked carboxy- terminal telopeptide of type I collagen: a new serum marker of bone collagen degradation. Clin Chem 1993;39:635-40. 19 Risteli J, Niemi S, Trivedi P, Maentausta O, Mowat AP, Risteli L. Rapid equilibrium radioimmunoassay for the amino-terminal propeptide of human type III procollagen. Clin Chem 1988;34:715-18.

20 Crofton PM, Wade JC, Taylor MR, Holland CV. Serum concentrations of carboxyl-terminal propeptide of type I procollagen, amino-terminal propeptide of type III procollagen, cross-linked carboxyl-terminal telopeptide of type I collagen, and their interrelationships in schoolchildren. Clin Chem 1997;43:1577-81.

21 Trivedi P, Risteli J, Risteli L, Hindmarsh PC, Brook CG, Mowat AP. Serum concentrations of the type I and III procollagen propeptides as biochemical markers of growth velocity in healthy infants and children and in children with velocity in healthy infants and children and in chil
growth disorders. Pediatr Res 1991;30:276-80.

22 Robins SP, Woitge H, Hesley R, Ju J, Seyedin S, Seibel MJ. Direct, enzyme-linked immunoassay for urinary deoxypyridinoline as a specific marker for measuring bone resorption. F Bone Miner Res 1994;9:1643-9.

23 Hanson DA, Weis MA, Bollen AM, Maslan SL, Singer FR, Eyre DR. A specific immunoassay for monitoring human bone resorption: quantitation of type I collagen cross-linked N-telopeptides in urine. F Bone Miner Res 1992;7:1251-8.

24 Bollen AM, Eyre DR. Bone resorption rates in children monitored by the urinary assay of

25 Peterson CG, Enander I, Nystrand J, Anderson AS, Nilsson L, Venge P. Radioimmunoassay of human eosinophil cationic protein (ECP) by an improved method. Establishcationic protein (ECP) by an improved method. Establish-
ment of normal levels in serum and turnover in vivo. Clin Exp Allergy 1991;21:561-7.

26 Kristjansson S, Strannegard IL, Strannegard O, Peterson C, Enander I, Wennergren G. Urinary eosinophil protein X in children with atopic asthma: a useful marker of antiinflammatory treatment. F Allergy Clin Immunol 1996;97:1179-87.

27 Lugosi E, Halmerbauer G, Frischer T, Koller DY. Urinary eosinophil protein X in relation to dis

28 Quanjer PH, Tammeling GJ, Cotes JE, Pedersen OF, Peslin $\mathrm{R}$, Yernault J-C. Lung volumes and forced ventilatory flows. Eur Respir f 1993;6(suppl 16):5-40.

29 Wolthers OD, Heuck C, Hansen M, Kollerup G. Serum and urinary markers of types I and III collagen turnover during short-term prednisolone treatment in healthy adults. Scand f Clin Lab Invest 1997;57:133-9.

30 Wolthers OD, Pedersen S. Short term linear growth in asthmatic children during treatment with prednisolone. $B M F$ 1990;301:145-8.

31 Birkebæk NH, Esberg G, Andersen K, Wolthers OD, Hassager C. Bone and collagen turnover during treatment with inhaled dry powder budesonide and beclomethasone dipropionate. Arch Dis Child 1995;73:524-7.

32 Agertoft L, Pedersen S. Short-term knemometry and urine cortisol excretion in children treated with fluticasone propionate and budesonide: a dose response study. Eur Respir F 1997;10:1507-12.

33 Wolthers OD, Pedersen S. Controlled study of linear growth in asthmatic children during treatment with inhaled glucocorticosteroids. Pediatrics 1992;89:839-42.

34 Wolthers OD, Konstantin Hansen K, Pedersen S, Petersen KE. Knemometry in the assessment of short-term linear growth in a population of healthy schoolchildren. Horm Res growth in a pop

35 Risteli J, Risteli L. Analysing connective tissue metabolites in human serum. Biochemical, physiological and methodological aspects. F Hepatol 1995;22:77-81.

36 Risteli J, Elomaa I, Niemi S, Novamo A, Risteli L. Radioimmunoassay for the pyridinoline cross-linked carboxyterminal telopeptide of type I collagen: a new serum marker of bone collagen degradation. Clin Chem 1993;39:635-40.

37 Heuck C, Wolthers OD, Kollerup G, Hansen M, Teisner B. Adverse effects of inhaled budesonide $800 \mu \mathrm{g}$ on growth and collagen turnover in asthmatic children: a double blind comparison of once versus twice daily administration. $\mathcal{F}$ Pediatr 1998;133:608-12.

38 Ju HS, Leung S, Brown B, et al. Comparison of analytical performance and biological variability of three bone resorption assays. Clin Chem 1997;43:1570-6.

39 Garnero P, Gineyts E, Arbault P, Christiansen C, Delmas PD. Different effects of bisphosphonate and estrogen therapy on free and peptide-bound bone cross-links excretion. F Bone Miner Res 1995;10:641-9.

40 Blumsohn A, Naylor KE, Assiri AM, Eastell R. Different responses of biochemical markers of bone resorption to bisphosphonate therapy in Paget disease. Clin Chem 1995; 41:1592-8.

41 Kamel S, Brazier M, Rogez JC, et al. Different responses of free and peptide-bound cross-links to vitamin D and calcium supplementation in elderly women with vitamin D
insufficiency. $\mathcal{F}$ Clin Endocrinol Metab 1996;81:3717-21.

42 Abildgaard N, Rungby J, Glerup H, et al. Long-term oral pamidronate treatment inhibits osteoblastic function in multiple myeloma. Eur ₹ Haematol 1998;61:128-34.

43 Colwell A, Eastell R. The renal clearance of free and conjugated pyridinium cross-links of collagen. F Bone Miner Res 1996;11:1976-80.

44 Zimmerman B, Lanner A, Enander I, Zimmerman RS, Peterson CG, Ahlstedt S. Total blood eosinophils, serum eosinophil cationic protein and eosinophil protein $\mathrm{X}$ in childhood asthma: relation to disease status and therapy. Clin Exp Allergy 1993;23:564-70. 